\title{
Molecular genetics as a 'probe' in ophthalmology
}

Under the seemingly endless assault of molecular techniques, an ever increasing number of genes for inherited defects in vision are being identified and disease specific mutations characterised. In this issue, Fullwood et al present the clinical features and the results of linkage analysis of a family with $\mathrm{X}$ linked exudative vitreoretinopathy ( $\mathrm{X}$ linked FEVR). Clinically, this condition is characterised by retinal traction, peripheral vitreous opacities, subretinal and intraretinal exudates, and retinal detachment and has been described in families with both $\mathrm{X}$ linked and autosomal dominant inheritance. ${ }^{1}$

Although polymorphisms at 20 loci on the $\mathrm{X}$ chromosome were studied, owing to the small number of individuals available in one family and the limited amount of information that can be obtained from some of the polymorphisms, it has not been possible for Fullwood et al to pinpoint the location of the gene precisely. Their results fail to prove linkage at any of the loci studied but do however point to two regions, $\mathrm{Xp11}$ and $\mathrm{Xq} 21.3$, which require further analysis in this and other similar families.

This highlights one of the essential features of the many successful studies which have produced candidate genes for rare inherited diseases. In order to ensure that linkage studies will produce useful information, it is necessary to have access to as many large multigenerational families as possible for DNA analysis. It is therefore important for clinicians to consider storing the DNA of known affecteds, their spouses, and sibs - affected or unaffected - so that, in collaboration with others, the molecular pathology of other rare diseases may be further elucidated.

Using such an approach, an international collaboration of workers has recently published linkage information for the autosomal dominant form of familial exudative vitreoretinopathy (adFEVR). ${ }^{2}$ Studying a large German family and a smaller Dutch family these workers made use of highly informative polymorphisms to show that the gene for this condition maps on chromosome $1 \mathrm{lq}$ and it now remains for them to extend this work to identify possible candidate genes.

Two groups recently published their results on the isolation and characterisation of the gene at Xpl1.2-p11.3 for Norrie disease. This is another rare $\mathrm{X}$ linked disorder characterised by congenital blindness, retinal dysplasia with pseudoglioma, and often mental retardation and progressive sensorineural deafness. ${ }^{34}$ This familial condition is one of the differential diagnoses which may be considered for $\mathrm{X}$ linked FEVR. It has been suggested by Fullwood that these two conditions may be allelic but as yet there is little hard evidence to support such a hypothesis. However, in both conditions defective vascularisation occurs during the development of the eye and it is possible that this occurs at different times during development in these two conditions producing differences in the type and severity of congenital malformation. It is thus possible that different types of mutations within the one gene could produce these two phenotypes by a differential timescale of expression.

Mutations including deletions and point mutations have now been identified within the coding regions of the candidate gene for Norrie disease. ${ }^{5}$ The gene codes for a cDNA of $1.9 \mathrm{~kb}$ which produces an apparently previously unknown protein with no significant homology to known proteins, therefore suggesting a gene of 'new' function.

Other conditions for which genes have recently been identified include retinitis pigmentosa (RP) and choroideraemia.
Mutations in two genes, the rod photoreceptor, rhodopsin on chromosome $3 \mathrm{q}^{67}$ and another transmembrane photoreceptor gene, peripherin on chromosome $6 \mathrm{p},{ }^{8}$ have been shown to segregate with some forms of autosomal dominant RP. Linkage studies have also demonstrated that other genes, one on the pericentromeric region of chromosome $8 \mathrm{q} 21-\mathrm{q} 22^{\circ}$ and another, at an as yet unknown locus, can cause the autosomal dominant forms of RP. ${ }^{10}$ Mutations in the rhodopsin gene have also been found in a large family with dominant congenital complete nyctalopia."

Recently, mutations in the gene, ROM1, on chromosome $11 \mathrm{q}$, have been found to cosegregate with the RP phenotype in a small family. Linkage studies also implicate this locus or others nearby in Usher syndrome type I and Best vitelliform macular dystrophy. ${ }^{12}$ ROMl and peripherin are two of a family of retinal proteins found in the rod photoreceptors; they are structurally similar and non-covalently associated in vivo.

In only one case to date has a gene been implicated in an autosomal recessive form of $R P$ and in this individual, the result of a consanguinous marriage, it was a null mutation in a rhodopsin gene which was the cause. ${ }^{13}$ In contrast, another null mutation predicted to produce only a very small fragment of the peripherin protein, segregates with a dominant form of retinitis punctata albescens. ${ }^{14}$

The gene for choroideraemia (hCHM), an X linked progressive degeneration of the choroid and the retina was identified two years ago $^{15}$ and now mutations including deletions, point mutations, and aberrant splicing at the exon/ intron junction have been found to be associated with the abnormal phenotype. ${ }^{16}$ An autosomal homologue of this gene, human choroideraemia-like (hCHML) gene, colocalises with the Usher syndrome type II locus on the distal part of chromosome lq. ${ }^{17}$ As there are clinical similarities between these two conditions, hCHML must now be considered a candidate gene for Usher syndrome type II.

As can be seen from this brief review, different genes have now been shown to produce clinically similar phenotypes (for example, RP) and different mutations in the same gene can produce apparently different clinical phenotypes (for example, peripherin mutations).

Studies such as those described above and as presented by Fullwood et al in this journal will continue to produce information on the genes coding for novel proteins involved in the development and function of the eye. The logical extensions of such work will then provide us with an understanding of the molecular mechanisms causing these diseases and eventually improve our knowledge of the stages of normal neurodevelopment.

NEVA HAITES

Department of Medical Genetics,

Aberdeen Royal Infirmary,

Foresterhill, Aberdeen AB9 2ZB

1 Plager DA, Orgel IK, Ellis FD, Hartzer M, Trese MT, Shastry BS. X-linked recessive familial exudative vitreoretinopathy. Am f Ophthalmol 1992 114: 145-8.

2 Li Y, Muller B, Fuhrmann C, van Nouhuys CE, Laqua H, Humphries P, et al. The autosomal dominant familial exudative vitreoretinopathy locus maps on $11 \mathrm{q}$ and is closely linked to D11S533. Am 7 Hum Genet 1992; 51: 749-54.

3 Chen Z-Y, Hendriks RW, Jobling MA, Powell JF, Breakefield XO, Sims KB, et al. Isolation and characterization of a candidate gene for Norrie disease. Nature Genetics 1992; 1: 204-8.

4 Berger W, Meindl A, van de Pol TJR, Cremers FPM, Ropers HH, Doerner C et al. Isolation of a candidate gene for Norrie disease by positional cloning. Nature Geveric $1992,1,199-203$.

5 Berger W, van de Pol D, Warburg M, Gal A, Bleeker-Wagemakers L, de Silva $\mathrm{H}$, et al. Mutations in the candidate gene for Norrie disease. Hum Molec Gene H,et al. Mutations

6 Humphries P, Kenna P, Farrar GJ. On the molecular genetics of autosomal dominant retinitis pigmentosa. Progress in Retinal Research. (in press). 
7 Bell C, Converse CA, Collins MF, Esakowitz L, Kelly KF, Haites NE. Autosomal dominant retinitis pigmentosa (ADRP): a rhodopsin mutation in a Scottish family. F Med Genet 1992; 29: 667-8.

8 Farrar GJ, Kenna P, Jordan SA, Kumar-Singh R, Humphries MM, Sharp EM, et al. A three-base-pair deletion in the peripherin-RDS gene in one form of retinitis pigmentosa. Nature 1991; 354: 478-80.

9 Daiger SP, Blanton SH, Sadler LA, Cottingham AW, Wagner M, Heckenlively JR. Linkage mapping of one form of autosomal dominant retinitis pigmentosa (RP1) to 8q21-q22. Am F H um Genet 1992; 51: A185.

10 Jordan SA, del Rio T, Soriano N, Garcia-Sandoval B, Kenna P, Ayuso C, et al. Au SA, del Autosomal dominant retinitis pigmentosa (adRP). exclusion of a gene from three mapped loci provides evidence for the existence of a fourth locus. Hum

1 Sieving PA, Richards JE, Bingham EL, Naarendorp F. Dominant congenital complete nyctalopia and Gly90Asp rhodopsin mutation. Invest Ophthalmol Vis Sci 1992; 33: 1397.

12 Bascom RA, Liu L, Chen J, Duncan A, Kimberling WJ, Moller CG, et al. ROM 1: a candidate gene for autosomal dominant retinitis pigmentosa
(ADRP), Usher syndrome type 1, and Best vitelliform macular dystrophy. Am f Hum Genet 1992; 151: A6.

13 Rosenfeld PJ, Cowley GS, McGee TL, Sandberg MA, Berson EL, Dryja TP. A null mutation in the rhodopsin gene causes rod photoreceptor dysfunction and autosomal recessive retinitis pigmentosa. Nature Genetics 1992; 1: 209-13.

14 Kajiwara K, Sandberg MA, Berson EL, Dryja TA. A null mutation in the human RDS/peripherin gene in a family with autosomal dominant retinitis punctata albescens. Am $\mathcal{F}$ Hum Genet 1992; 151: A6.

15 Cremers FPM, van de Pol TJR, van Kerkhoff EPM, Wieringa B, Ropers HH Cloning of a gene that is rearranged in patients with choroideraemia. Nature 1990; 347: 674-7.

16 Sankila EM, Tolvanen R, van den Hurk AJM, Cremers FPM, de la Chapelle A. Aberrant splicing of the CHM gene is a significant cause of choroideraemia.

17 Cremers FPM, Molloy CM, van de Pol DJR, van den Hurk JAJM, Bach I, van Kessel HMG, et al. An autosomal homologue of the choroideremia gene colocalizes with the Usher syndrome type II locus on the distal part of chromosome 1q. Hum Molec Genet 1992; 1: 71-5. 